\title{
Aplikasi Metode Penetapan Kadar Rutin Parasetamol PT. Kimia Farma, Tbk Secara HPLC pada Sediaan Tablet Generik dan Bermerek di Medan
}

\author{
Suprianto ${ }^{1)}$, Darwin Syamsul ${ }^{2)}$, dan Muhammad Deddy Harfiansyah ${ }^{3)}$ \\ ${ }^{1,2,3}$ Fakultas Farmasi, Institut Kesehatan Helvetia Medan \\ Corresponding author: ekahasbi@gmail.com
}

\begin{abstract}
Paracetamol is a drug that is analgesic and antipyretic, which is produced as a generic or branded drug. The research objective was to determine the quality based on paracetamol levels in generic and branded tablet preparations circulating in Medan. The research used HPLC Alliance e2696 UV / Visible Detector 2489, Column $\mu$ Bondapak ${ }^{\mathrm{TM}} \mathrm{C}-18$ : $10 \mu \mathrm{m}$ 125A 3.9x300 mm, UV-Vis Spectrophotometer Agilent 8453. The method used was a routine assay method for paracetamol PT. Kimia Farma. The results showed that the paracetamol content in the tablet dosage was $97.05 \%$ $106.04 \%$, according to the Indonesian Pharmacopoeia Edition V, not less than $90 \%$ and not more than $110 \%$.
\end{abstract}

Keywords: Levels, paracetamol, tablets, HPLC

\section{Abstrak}

Parasetamol merupakan salah satu obat yang bersifat analgesik dan antipiretik, yang diproduksi sebagai obat generik maupun bermerek. Tujuan penelitian untuk mengetahui mutu berdasarkan kadar parasetamol dalam sediaan tablet generik dan bermerek yang beredar di Medan. Penelitian menggunakan HPLC Alliance e2696 Detector UV/Visible 2489, Column $\mu$ Bondapak ${ }^{\mathrm{TM}} \mathrm{C}-18: 10 \mu \mathrm{m}$ 125A 3,9x300 mm, Spektrofotometer UV-Vis Agilent 8453. Metode yang digunakan merupakan metote penetapan kadar rutin parasetamol PT. Kimia Farma. Hasil penelitian menunjukkan bahwa kadar parasetamol dalam sediaan tablet sebesar 97,05\% - 106,04\%, sesuai Farmakope Indonesia Edisi $\mathrm{V}$, tidak kurang dari $90 \%$ dan tidak lebih dari $110 \%$.

Kata Kunci: Kadar, parasetamol, tablet, HPLC

\section{PENDAHULUAN}

Sediaan obat generik biasa dipandang masyarakat sebagai obat yang tidak berkualitas dibandingkan obat bernerek. Harga obat generik lebih murah dibandingkan obat bermerek menyebabkan asumsi masyarakat semakin kuat bahwa obat generik tidak berkualitas. Informasi mutu obat generik di kalangan masyarakat awam sangat minim, sehingga masyarakat tidak percaya bahwa obat generik memiliki kualitas yang tidak berbeda dengan obat bermerek (MenKes RI 2010). Kontrol kualitas obat sangat penting dalam menjamin kemampuan terapi dari sediaan obat yang beredar di masyarakat. Penetapan kadar sediaan merupakan salah satu kontrol kualitas obat, baik tablet, kapsul dan sediaan lainnya harus sesuai kriteria yang disyaratkan Farmakope Indonesia Edisi V (Idris and Widjajarta 2006; Yusuf 2016).<smiles>CC(=O)Nc1ccc(O)cc1</smiles>

Gambar 1. Struktur Parasetamol (Kemenkes RI 2014)

Parasetamol atau 4-Hidroksiasetanilida dengan sinonim asetaminofen, rumus molekul $\mathrm{C}_{8} \mathrm{H}_{9} \mathrm{NO}_{2}$ dan rumus struktur seperti Gambar 1, berbentuk serbuk hablur; putih; tidak berbau; rasa sedikit pahit, larut dalam air mendidih dan dalam $\mathrm{NaOH} 1 \mathrm{~N}$ serta mudah larut dalam etanol (Depkes R I 1995). Parasetamol merupakan salah satu analgesik dan antipiretik yang relatif aman terhadap lambung, dan 
antipiretik pilihan untuk anak-anak maupun ibu hamil atau menyusui. Namun, parasetamol menyebabkan sirosis di hati jika digunakan dalam dosis besar (Cairns 2004; Agus Wibowo 2009).

Penetapan kadar parasetamol dalam sediaan tablet dapat dilakukan dengan berbagai metode, antara lain: volumetrik (Naldi 2010), spektrofotometri UV, spektrofotometri sinar tampak, spektrofotometri Fourier Transform Infra Red (FTIR) (Gandjar and Rohman 2018) atau High Pressure Liquid Chromatography (HPLC) (Yulyarti, Rifai, and Yulianty 2018). Metode HPLC sederhana, lebih baik, tepat, akurat, ekonomis, selektif, sensitif dan spesifik (Suprianto 2018).

Sediaan yang mengandung parasetamol banyak diproduksi dan diedarkan baik sebagai obat tunggal maupun campuran dalam bentuk sirup dan tablet (Ansel 1989). Salah satu sebab parasetamol sebagai obat pilihan analgesik dan antipiretik karena efek samping yang relatif kecil, disamping itu harga parasetamol relatif murah sehingga terjangkau oleh masyarakat (Agus Wibowo 2009). Parasetamol dan obat sejenis secara umum memiliki efektivitas sama dalam meredakan nyeri dan parasetamol tidak terlalu mengiritasi lambung (Gunawan, Setiabudy, and Nafrialdi 2007). Alasan tersebut menjadi dasar parasetamol sering digunakan pada usia lanjut dan pada kelompok rentan, seperti wanita hamil, asma, dan ulkus lambung (Zullies 2010).

\section{METODE PENELITIAN}

\section{Alat dan Material}

Alat-alat yang digunakan, antara lain: HPLC (Alliance e2696 Detector UV/Visible 2489), Ultrasonic Bath Digitals (ELMA Type D-78224), Column $\mu$ Bondapak ${ }^{\mathrm{TM}} \mathrm{C} 1810 \mu \mathrm{m}$ 125A 3,9 x

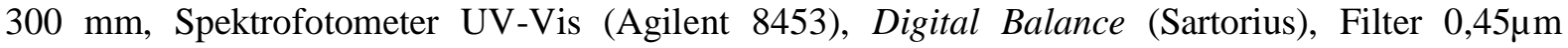
(Phenex NY), dan Alat-alat gelas (Pyrex). Bahan yang digunakan terdiri dari baku pembanding parasetamol (Anqiu Lu'an Pharmaceutical), metanol Grade HPLC (J.T.Baker), aquabidest (PT. Ikapharmindo Putramas). Sampel parasetamol dilakukan dengan metode purposive sampling. Sampel penelitian sebanyak 10 sampel yang terdiri dari 5 generik dan 5 bermerek dari beberapa Apotek di kota Medan

\section{Pembuatan Larutan}

Fase gerak yang digunakan dibuat dari campuran aquabidest dan methanol dengan perbandingan $3: 1$, kemudian difilter $(0,45 \mu \mathrm{m})$ dengan bantuan pompa vakum (Kemenkes RI 2014). Larutan baku induk dibuat dengan menimbang parasetamol baku sebanyak $50 \mathrm{mg}$, dilarutkan dalam fase gerak 20 $\mathrm{ml}$, di-gassing dengan ultrasonik selama 15 menit, dan ditambahkan fase gerak hingga batas tanda $100 \mathrm{ml}$ dan dihomogenkan (Kemenkes RI 2014). Larutan sampel dibuat dari $60 \mathrm{mg}$ serbuk tablet parasetamol (setara dengan $50 \mathrm{mg}$ parasetamol). Serbuk dimasukkan dalam labu ukur $100 \mathrm{ml}$, ditambahkan $20 \mathrm{ml}$ fase gerak, di-gassing selama 15 menit, dan ditambahkan kembali fase gerak sampai batas tanda $100 \mathrm{ml}$ dan dihomogenkan. Kemudian dipipet $1 \mathrm{ml}$ dan diencerkan dengan fase gerak sampai $50 \mathrm{ml}$, dan dihomogenkan, perlakuan diulang tiga kali (Kemenkes RI 2014).

\section{Penentuan Panjang Gelombang}

Panjang gelombang maksimum yang akan digunakan pada detektor HPLC ditentukan dengan menggunakan Spektrofotometer UV-Vis (Agilent 8453). Panjang gelombang maksimum ditentukan dengan scanning larutan baku parasetamol pada konsentrasi $10 \mathrm{ppm}$ dengan menggunakan pada rentang panjang gelombang 200-300 $\mathrm{nm}$.

\section{Pembuatan Kurva Kalibrasi}

Diencerkan larutan baku induk parasetamol hingga konsentrasi 2, 4, 6, 8 dan 10 ppm. Kemudian difilter dan diinjeksikan ke dalam HPLC pada panjang gelombang maksimum dengan volume injeksi $20 \mu \mathrm{l}$, fase gerak aqubidest-metanol (3:1), laju alir $1 \mathrm{ml} / \mathrm{menit}$, dan suhu kolom $30^{\circ} \mathrm{C}$. Kurva kalibrasi diperoleh dari hubungan antara konsentrasi larutan baku parasetamol dengan luas area di bawah kurva, kemudian ditentukan persamaan regresi dari kurva kalibrasi.

\section{Penetapan Kadar Parasetamol}

Metode yang digunakan merupakan metode rutin penetapan kadar parasetamol PT. Kimia Farma. Sampel diinjeksikan volume injeksi $20 \mu$ l, fase gerak aqubidest-metanol (3:1), laju alir $1 \mathrm{ml} / \mathrm{menit}$, dan suhu kolom $30^{\circ} \mathrm{C}$. 


\section{HASIL DAN PEMBAHASAN}

Panjang gelombang maksimum parasetamol terdeteksi pada $243 \mathrm{~nm}$ (Gambar 2). Hasil penentuan panjang gelombang sesuai menurut Farmakope Indonesia Edisi V. Kurva kalibrasi parasetamol dibuat dengan deteksi luas area di bawah kurva pada konsentrasi larutan baku induk parasetamol 2, 4, 6, 8 dan $10 \mathrm{ppm}$ pada panjang gelombang $243 \mathrm{~nm}$ dengan fase gerak aquabidest-metanol (3:1). Data absorbansi, garis regresi dan overlay kromatogram kurva kalibrasi parasetamol masing-masing dilihat pada Tabel 1, Gambar 3, dan Gambar 4.

Data Tabel 1 digunakan untuk menetukan persamaan regresi dari kurva kalibrasi parasetamol dan dihasilkan persamaan regresi $\mathrm{Y}=129204 \mathrm{X}+16557$ dengan koefisien korelasi (r) sebesar 0,999 . Nilai koefisien korelasi memenuhi syarat linearitas, yaitu $r \geq 0,999$.

Data hasil penetapan kadar parasetamol generik dan bermerek di kota Medan dapat dilihat pada Tabel 2. Tabel 2 menunjukkan bahwa kadar terendah dan tertinggi tablet parasetamol generik sebesar $97,046 \%$ (D) dan 105,969\% (A), sedangkan kadar terendah dan tertinggi parasetamol bermerek sebesar 92,825\% (S) dan 106,039\% (R). Tablet parasetamol mengandung tidak kurang dari 90\% dan tidak lebih dari $110 \%$ dari jumlah yang tertera pada etiket (Kemenkes RI 2014). Dengan demikian kadar parasetamol baik generic maupun bermerek masih berada pada rentang yang ditetapkan dalam Farmakope Indonesia V. Hasil uji komparasi dua sisi $(\alpha=0,05)$ dari rata-rata kadar tablet generik dengan bermerek tidak menunjukkan perbedaan yang signifikan (F-test: $\mathrm{p}=0,372),(\mathrm{t}$-test: $\mathrm{p}=0,230$ ) dan (Welch method: $\mathrm{p}=$ 0,237) (Santoso 2010; Ari Wibowo 2017)

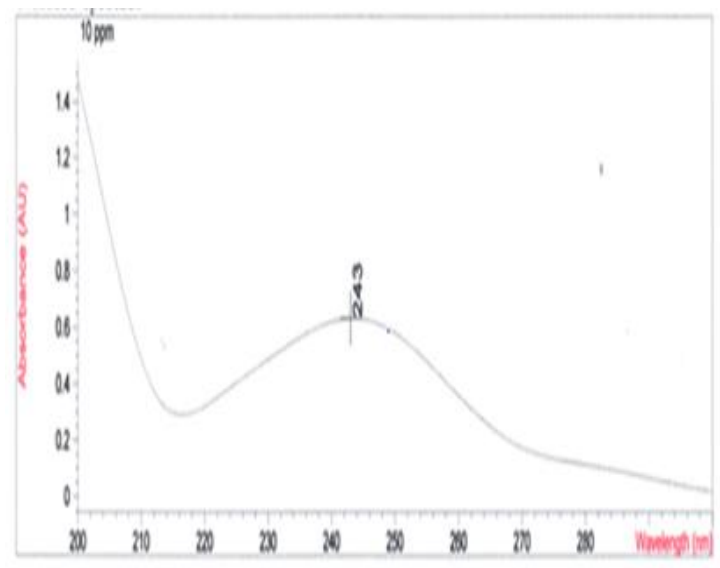

Gambar 2. Panjang Gelombang Maksimum Parasetamol dalam Fase Gerak

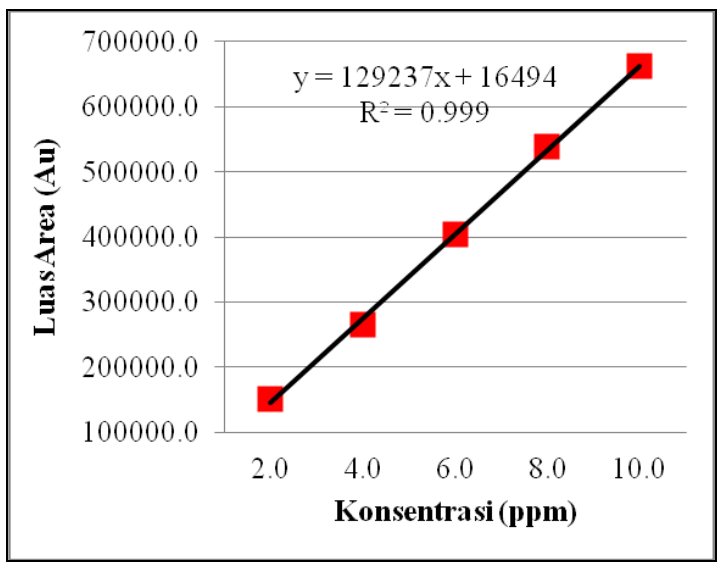

Gambar 3. Kurva Kalibrasi Parasetamol dalam dalam Fase Gerak
Tabel 1. Data Kurva Kalibrasi Parasetamol

\begin{tabular}{ll} 
Konsentrasi (ppm) & Luas Area (AU) \\
\hline 2,0 & 152135,25 \\
4,0 & 264982,29 \\
6,0 & 404178,70 \\
8,0 & 537831,53 \\
10,0 & 661895,51 \\
\hline
\end{tabular}

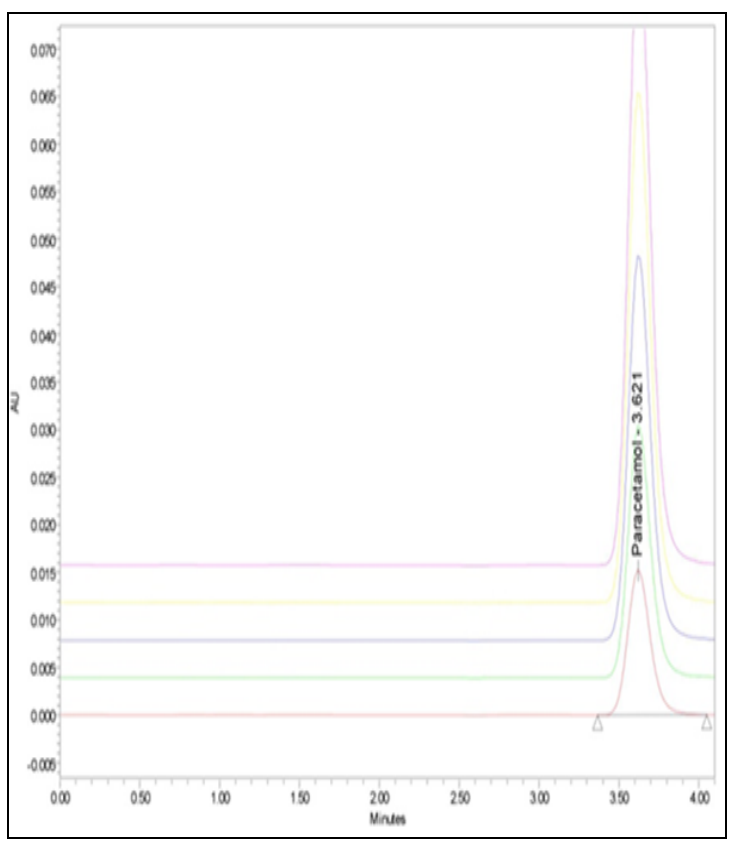

Gambar 4. Overlay Kromatogram Kurva Kalibrasi Parasetamol Fase Gerak 
Tabel 2. Kadar Parasetamol dalam Sediaan Tablet Generik dan Bermerek di Kota Medan

\begin{tabular}{|c|c|c|c|c|c|c|c|}
\hline \multicolumn{4}{|c|}{ Parasetamol Generik } & \multicolumn{4}{|c|}{ Parasetamol Bermerek } \\
\hline Produk & $\begin{array}{l}\text { Luas } \\
\text { Area } \\
(\mathrm{AU}) \\
\end{array}$ & $\begin{array}{c}\text { Kadar } \\
(\%)\end{array}$ & $\begin{array}{c}\text { Rata-rata } \\
(\%)\end{array}$ & Produk & $\begin{array}{l}\text { Luas } \\
\text { Area } \\
\text { (AU) }\end{array}$ & $\begin{array}{c}\text { Kadar } \\
(\%)\end{array}$ & Rata-rata $(\%)$ \\
\hline A & $\begin{array}{l}694058 \\
689899 \\
692127\end{array}$ & $\begin{array}{l}106,301 \\
105,622 \\
105,984\end{array}$ & 105,969 & $\mathrm{P}$ & $\begin{array}{l}618078 \\
620040 \\
615410\end{array}$ & $\begin{array}{l}94,664 \\
94,964 \\
94,255\end{array}$ & 94,628 \\
\hline B & $\begin{array}{l}683726 \\
682103 \\
682261\end{array}$ & $\begin{array}{l}104,718 \\
104,470 \\
104,494\end{array}$ & 104,561 & Q & $\begin{array}{l}643961 \\
642281 \\
644255\end{array}$ & $\begin{array}{l}98,589 \\
98,351 \\
98,673\end{array}$ & 98,538 \\
\hline $\mathrm{C}$ & $\begin{array}{l}688620 \\
685696 \\
689083\end{array}$ & $\begin{array}{l}105,468 \\
105,020 \\
105,518\end{array}$ & 105,335 & $\mathrm{R}$ & $\begin{array}{l}689230 \\
692849 \\
695234\end{array}$ & $\begin{array}{l}105,519 \\
106,116 \\
106,481\end{array}$ & 106,039 \\
\hline $\mathrm{D}$ & $\begin{array}{l}632011 \\
634539 \\
634721 \\
\end{array}$ & $\begin{array}{l}96,759 \\
97,185 \\
97,193 \\
\end{array}$ & 97,046 & $S$ & $\begin{array}{l}606251 \\
608834 \\
603123 \\
\end{array}$ & $\begin{array}{l}92,853 \\
93,248 \\
92,374\end{array}$ & 92,825 \\
\hline $\mathrm{E}$ & $\begin{array}{l}677459 \\
676469 \\
675010\end{array}$ & $\begin{array}{l}103,759 \\
103,607 \\
103,383\end{array}$ & 103,583 & $\mathrm{~T}$ & $\begin{array}{l}685521 \\
679674 \\
681706\end{array}$ & $\begin{array}{l}104,993 \\
104,098 \\
104,388\end{array}$ & 104,493 \\
\hline
\end{tabular}

\section{KESIMPULAN}

Hasil penelitian yang dilakukan terhadap tablet paracetamol generik dan bermerek sesuai dengan persyaratan yang tercantum dalam Farmakope Indonesia Edisi V. Hasil pemeriksaan mutu yang dilakukan terhadap tablet parasetamol generik dan bermerek dengan penetapan kadar memenuhi persyaratan tidak kurang dari $90 \%$ dan tidak lebih dari $110 \%$. Hasil menunjukkan bahwa kadar tablet parasetamol generik dan bermerek tidak berbeda nyata. Terbukti tidak ada perbedaan kadar zat berkhasiat tablet parasetamol generik dengann bermerek, dengan demikian masyarakat diharapkan tidak meragukan lagi mutu dari tablet parasetamol generik.

\section{DAFTAR PUSTAKA}

Ansel, Howard C. 1989. Pengantar Bentuk Sediaan Farmasi. Jakarta: Universitas Indonesia Press.

Cairns, Donald. 2004. Intisari Kimia Farmasi. Jakarta: Buku Kedokteran EGC.

Depkes R I. 1995. Farmakope Indonesia. Edisi IV. Jakarta: Depkes RI.

Gandjar, Ibnu Gholib, and Abdul Rohman. 2018. Spektroskopi Molekuler Untuk Analisis Farmasi. Yogyakarta: UGM Press.

Gunawan, Sulistia Gan, R Setiabudy, and Elysabeth Nafrialdi. 2007. Farmakologi Dan Terapi. Edisi V. Jakarta: Departemen Farmakologi dan Terapeutik FKUI.

Idris, F, and M Widjajarta. 2006. Obat Generik Harga Murah Tapi Mutu Tidak Kalah. Jakarta: PBIDI.

Kemenkes RI. 2014. Farmakope Indonesia. Edisi V. Jakarta: Ditjen. Bina Kefarmasian dan Alat Kesehatan Republik Indonesia.

MenKes RI. 2010. Peraturan Menteri Kesehatan Nomor: HK.02.02/Menkes/068/I/2010 Tentang Kewajiban Menggunakan Obat Generik Di Fasilitas Pelayanan Kesehatan Pemerintah. Jakarta: Departemen Kesehatan Republik Indonesia.

Naldi, Eki. 2010. "Penetapan Kadar Campuran Ibuprofen Dan Parasetamol Dalam Sediaan Tablet Secara Volumetri." Skripsi, Universitas Sumatera Utara.

Santoso, Singgih. 2010. Statistik Non Parametrik. Jakarta: Elex Media Komputindo.

Suprianto. 2018. "Optimization of Mobile Phase for Simultaneous Determination of Sweeteners, Preservatives and Dyes by UFLC.” International Journal of ChemTech Research 11 (1): 56-63. 
https://doi.org/10.5281/ZENODO.1246180.

Wibowo, Agus. 2009. Cerdas Memilih Obat Dan Mengenali Penyakit. Jakarta: PT. Lingkar Pena Kreativa.

Wibowo, Ari. 2017. "Uji Chi-Square Pada Statistika Dan SPSS.” Jurnal Ilmiah Sinus 4 (2): 37-46.

Yulyarti, Endhah, Yusnita Rifai, and Risfah Yulianty. 2018. "Ppenetapan Kadar Parasetamol, Kafein, Dan Propifenazon Secara Simultan Dalam Sedian Tablet Dengan Metode KCKT." Majalah Farmasi Dan Farmakologi 22 (1): 1-4. https://doi.org/https://doi.org/10.20956/mff.v22i1.5687. Yusuf, Faisal. 2016. "Studi Perbandingan Obat Generik Dan Obat Dengan Nama Dagang." Jurnal Farmanesia 3 (1): 5-10.

Zullies, Ikawati. 2010. Cerdas Mengenali Obat. Yogyakarta: Kanisiuss. 